\title{
How Pervasive are Euro-Politics? Effects of EU Membership on a New Member State*
}

\author{
GERDA FALKNER \\ Max-Planck-Institute for the Study of Societies, Cologne
}

\begin{abstract}
While the consequences of becoming an EU Member State for national policies are usually the core concern of pre-membership debates and of postaccession assessments, studies of the effects of European integration on the political systems of the Member States have so far been less numerous. Among the new EU members, which are ideal cases for studying domestic accession effects, Austria is a particularly challenging case in terms of topdown impact on the national political system. A number of specific precautions were taken in order to protect typical features of the national political system (notably the traditional roles of parliament, Länder and social partners) from being eroded in the multi-level system. The basic research question of this article is whether or not these measures were actually successful. How 'sticky' is the EU upon closer inspection, i.e. how pervasive are its effects on adverse national structures? Can national measures, even at the constitutional level, outweigh specific consequences of participating in Euro-politics? If not (as the Austrian case indicates), why not? The conclusions distinguish specific Austrian variables from generalizable ones and discuss the findings in the light of the existing literature.
\end{abstract}

\footnotetext{
* This article draws on two studies of Austrian adaptation to EU membership (Falkner and Müller, 1998; Tálos and Falkner, 1996). Special thanks go to Rita Trattnigg for providing information on very recent developments in the Austrian parliament, and to Bernhard Kittel, Michael Nentwich, Susanne K. Schmidt, Emmerich Tálos, Helmut Voelzkow and two referees for their various comments.
} 


\section{Introduction}

Policy adaptation to EU standards often appears to be spectacular, but the effects of European integration on the political systems of the now 15 Member States have so far been studied less frequently (see also Bergman, 1997). However, they increasingly attract scholarship. The empirical case under scrutiny in this article is Austria, which joined the EU in January 1995. The experience of a new Member State is particularly enlightening since the 'trickling down' of European patterns can be studied almost as if under laboratory conditions. Actors as well as scientists may detect changes due to Europeanization ${ }^{1}$ more easily than in other national systems for two good reasons. First, adaptation happened only recently, so both politicians and bureaucrats and scientists can tell the difference more easily. Second, the changes were much more abrupt than in the original Member States. The entire acquis communautaire had to be implemented at once, which accounts for quite dramatic innovation in the space of only a few years. In the founding states, by contrast, the development from 'nation state' to 'Member State' (Sbragia, 1994) happened incrementally so that the impact was experienced in rather homeopathic doses. Therefore, effects of EU membership are often hard to distinguish from the impact of other variables in the overall process of political change (such as reforms for purely internal reasons or reactions to the internationalization of the economy in general). Although control of the dependent and independent variables is not unproblematic even in the case of the youngest EU members, it is much more difficult with respect to polities that joined before the internal market programme or right at the beginning of European integration.

Among the new EU members, Austria is a particularly challenging case in terms of top-down impact on the national political system. A number of specific precautions were taken in order to protect typical features of the national political system from being eroded in the multi-level system. The basic research question of this article is whether or not these measures were actually successful. How 'sticky' is the EU upon closer inspection, i.e. how pervasive are its effects on adverse national structures? Can national measures, even at the constitutional level, outweigh specific consequences of participating in Euro-politics (i.e. in the EU-level political system)? If not, why not? Answering these questions, with Austria as the case in point here, is not only empirically instructive. Insofar as the results can be generalized, they may furthermore help to shape realistic expectations of the domestic consequences of forthcoming EU enlargements. If 'defence' against Europeanization is

\footnotetext{
1 'Europeanization is an incremental process reorienting the direction and shape of politics to the degree that EC political and economic dynamics become part of the organizational logic of national politics and policy-making' (Ladrech, 1994, p. 69).
}

(C) Blackwell Publishers Ltd 2000 
already difficult (or even partly impossible) for stable and deeply rooted national systems, how much more problematic must it be for 'reform states' still in transition towards pluralist democracy?

The analysis will proceed along the following lines: initially, the anticipated effects on domestic politics as discussed in Austria prior to EU accession will be outlined (Section II). Efforts to preserve existing national patterns even under the condition of EU membership, along with their practical success, will then be analysed for parliament (Section III), Länder (IV) and social partners (V). The conclusions will go on to distinguish specific Austrian variables from generalizable ones, and present the findings in the light of the existing literature.

\section{Anticipation of EU Effects in Austria}

During the years preceding the Austrian accession to the EU, studies of the likely effects predicted manifold changes due to the significant differences between the political system of the EU, on the one hand, and Austria, on the other (see, notably, Gerlich and Neisser, 1994). Austria was a federal state with specific powers still resting with the nine provinces (Länder). Parliament was (at least formally) the gate-keeper of legislation. The social partners as the representatives of labour and employers, however, were in fact more influential in many issue areas (on the basic features of the Austrian political system, see Dachs et al., 1997).

A focal point of these studies was the expectation that the government and the administration would gain in political weight to the detriment of parliament. This issue was discussed less in terms of 'agency loss' (Moravcsik, 1994) and the likelihood of parliament's policy options being misrepresented by the government. Rather, it was framed as a relative loss of competencies for the legislature, hence in terms of the horizontal distribution of functions (Olsen, 1997). The government was to have its action capacity increased via privileged access to EU decision-making (Gerlich, 1994). Since it would regularly interact with the other governments in the EU Council of Ministers, it would participate in package deals and the relevant political give-and-take across issue-areas - which is in practice outside the control of other national actors. In the long run, the Austrian government could even be expected, as a consequence of its increasingly European involvement, to develop 'European' interests in addition to national ones, which might result in less parallelism between the views of ministers/administration and social partners than hitherto (Gerlich, 1994). ${ }^{2}$ The Austrian parliament, by contrast, would not only lose its

${ }^{2}$ Only a specific empirical analysis could confirm that such a development has actually taken place. In the absence of such a study, one can merely point to a few recent examples of conflicts of interest (Falkner, 1998 b) without as yet generalizing.

(c) Blackwell Publishers Ltd 2000 
monopoly on passing 'Austrian' legislation because of regulative competencies being shifted to the EU level (Neisser, 1994; Falkner, 1994); in general, the parliamentary character of the political system, ${ }^{3}$ in the sense of a decisive say for political representatives who are directly legitimated, would also suffer, it was feared. This concern corresponded to one major argument in the debate on the EU's 'democratic deficit', ${ }^{4}$ i.e. that national ministers in the Council (and de facto often bureaucrats in the working groups) are the crucial decision-makers at the EU level, not a legislature that can be held accountable in general elections. Although the European Parliament (EP) since Maastricht enjoys codecision powers in some areas, it is still involved in a purely consultative manner on a large number of issues. ${ }^{5}$ It is particularly where neither the EP nor the individual national parliaments can control the making of EU law which is binding on the Member States (most notably where majority voting is practised without the EP being a decisive co-legislator) that the 'democracy principle' of the Austrian constitution might be hampered, since the law would not be created by directly legitimated representatives of the citizens.

The most widely discussed and supposedly most 'typical' feature of the Austrian political system is the corporatist co-operation of the centralized peak associations of labour and management with the state in shaping public policies. The mainstream political science literature perceives corporatism as a two-dimensional phenomenon. The structural dimension refers to the existence of a corporatist system of interest groups, i.e. one 'in which the constituent units are organized into a limited number of singular, compulsory, noncompetitive, hierarchically ordered and functionally differentiated categories, recognized or licensed (if not created) by the state and granted a deliberate representational monopoly within their respective categories in exchange for observing certain controls of their selection of leaders and articulation of demands and supports' (Schmitter, 1974, p. 13). The procedural dimension concerns a pattern of policy formation with specific relations between government and organized interest groups (Lehmbruch, 1974), 'a mode of policy formation in which formally designated interest associations are incorporated within the process of authoritative decision-making and implementation. As such they are officially recognised by the state not merely as interest interme-

\footnotetext{
${ }^{3}$ Understood in a broad sense, including the EU as the 'first level' (Jeffery, 1997).

${ }^{4}$ Clearly, there are also other factors which account, according to various authors, for such a deficit, notably the lack of openness and transparency of EU-level decision-making, the absence of direct democratic elements, the fact that Euro-elections are still second-order elections, where often national issues are decisive, etc. (Abromeit, 1998; Føllesdal and Koslowski, 1997; Grande, 1996a; Nentwich, 1998; Weale and Nentwich, 1998; Zürn, 1996).

${ }^{5}$ On the state of EP involvement after Amsterdam, see for example Bieber (1997); Brok (1997); Falkner and Nentwich (2000); Nickel (1997); see also Shackleton in this issue.
}

(C) Blackwell Publishers Ltd 2000 
diaries but as co-responsible "partners" in governance and social guidance' (Schmitter 1981, p. 295).

In the Austrian case, both dimensions of corporatism are extremely well developed. There are a number of quite hierarchically organized 'chambers' (for business, labour, agriculture, etc.), i.e. interest groups set up by Austrian law where membership is obligatory. The classic social partner institutions in Austria are thus the Chamber of Business (Wirtschaftskammer Österreich), the Chamber of Labour (Bundesarbeitskammer), the Conference of Presidents of the Chambers of Agriculture (PRÄKO) and the encompassing Austrian trade union confederation (ÖGB). These pillars of 'social partnership' co-operate formally (e.g. in a plethora of working groups) and informally with the other political institutions, on a daily basis. Although there are (increasing) differences between policy and issue areas, it is quite common that draft legislation is negotiated between the social partners and/or the relevant ministry before being 'rubber-stamped' in parliament (for an overview and recent developments see Karlhofer and Tálos, 1999).

EU adhesion was not expected to put an end to this pattern of corporatism (or social partnership), ${ }^{6}$ but to change it in a 'substantial and speedy' way (Tàlos, 1994, p. 179; Korinek, 1994; Seidel, 1989; Wimmer and Mederer, 1990). Although it was clear from the beginning that EC law does not directly impinge on the organization of associations and on the structure of the system of interest representation (Zehetner and Haslinger, 1990), impulses for change were expected with regard to both the fields theoretically open for corporatist policy-making and the procedural dimension of interest involvement. As a direct effect of membership, the issues prone to joint decision-making by the Austrian social partners and 'the state' would be less numerous since decisions would be shifted to the EU level. As an indirect effect, pluralist patterns of interest group behaviour at the European level ('lobbying') were expected to trickle down into the Austrian system.

For the Länder, it was clear that a number of competencies which were still in their realm would be 'Europeanized' or at least severely encroached upon by EU law. Although the legislative powers of the Austrian Länder were already quite limited before 1994, the European Economic Area (EEA) and subsequently EU membership eroded them even more. Traditional competencies of the regions were, for example, in the fields of country planning, road construction (except Federal routes), the regulation of property markets (where it was common to discriminate against foreigners when it came to buying landed property, e.g. in Tyrol) and of some professions (such as skiing

\footnotetext{
${ }^{6}$ Although some features of the Austrian version of corporatism are country-specific, notably a basic consensus on macroeconomic goals and the multi-dimensionality of government-interest group relations (see Tálos, 1982; Tálos, 1985; Tálos and Kittel 1995), social partnership will be used in this contribution as a synonym for corporatism (as practised by most authors).
}

(c) Blackwell Publishers Ltd 2000 
or dancing instructors), the setting of economic incentives (funding), and wildlife and animal protection (e.g. the conditions of production on animal farms, the definition of cruelty to animals).

That supranational bodies would in future make decisions on many of these issues (i.e. that the level of decision-making would change from subnational to supranational) was not the only concern of Austrian Länder politicians and political scientists dealing with matters of federalism. Another issue was that the decision-makers at the supranational level would not be representatives of the Länder, since there is no codecision power for the subnational regional entities at the EU level. A shift of competencies would therefore occur not only from the national to the European level, but also from regional to federal representatives. Hence the changes for the Länder brought about by a prospective EU accession implied what was called a 'double erosion effect' (see, e.g., Dachs, 1994, p. 186 and his further references): influence on those matters which until then were regional ones would go to the national government in the EC Council of Ministers, not to an EC chamber composed of Länder representatives (which would have been considered as a minor evil by many). In turn, a reform of the national distribution of competencies between the central and the regional level was demanded (Dachs, 1994). Since the government conceded that this should happen parallel to EU accession (Weber, 1996, p. 50 ), it was hoped that a reform of the federal state would come as a positive side-effect of membership and as a pay-off for the negative consequences for the Länder.

From the viewpoint of the traditional Austrian 'model' of a political system, EU membership was thus expected to have significant consequences for several basic features (be it de facto or de jure), i.e. the role of parliament, social partnership and state-Länder relations. To counterbalance the predicted effects, a number of steps were taken or attempted (some significant, some rather symbolic).

\section{The Nationalrat}

\section{Efforts to Preserve National Traditions}

Even the constitution was changed to give the directly elected first chamber of the Austrian parliament extremely far-reaching powers to control the government in EU affairs. The Austrian model even exceeds the Danish one in this respect (Morass, 1996). Art. 23e of the Federal Constitution provides that the Nationalrat must be informed in good time about all EU-related projects by the responsible minister. On projects leading to mandatory law in areas which before would have needed national legislative scrutiny (this is notably the case when new EC directives or regulations are negotiated), the Nationalrat may 
issue an opinion which will bind the Austrian members of government in EUlevel negotiations and votes. The ministers can only ignore such a mandate if there are 'compelling reasons of foreign or integration policy', 7 and after another consultation with the MPs. Parliamentary scrutiny via negotiation mandates extends beyond legislative issues in the first pillar of the EU to include, notably, decisions in the framework of the Common Foreign and Security Policy, as well as Justice and Home Affairs. Where EU projects would lead to changes in the (rather extensive) body of Austrian "constitutional law,, 8 departure from a parliamentary opinion is legal only if the Nationalrat does not impede it after 'reasonable delay'.

In March 1996, the chairs and directors of the party delegations in the Nationalrat were also granted the right to participate and speak in the Austrian Council of Ministers, where in weekly sessions the national strategy for the EU Council is discussed. All ministers have to report on EU-related issues and problems which fall in their domain, including complaints filed with the EC Commission, cases at the ECJ and topics for discussion at the forthcoming meeting of the Committee of Permanent Representatives of the Member States at the EC. This serves the cross-ministerial co-ordination ${ }^{9}$ of EU affairs in Austria, but is only the 'tip of the iceberg' (see below).

That the Austrian Nationalrat was granted such far-reaching rights (for an international comparison, see Bergman, 1997) must be seen in the light of the debate on drawing closer to the EC, which had been going on since 1987. All major political actors had participated in it, and advocates of closer ties had an active interest in keeping opposition to EU membership low. Issues of democracy and the loss of competencies to be expected for the Austrian parliament had always been a major topic. Some compensatory measures were therefore considered essential from the beginning. In fact, a similar model for parliamentary participation in Euro-level decisions had already been established for the EEA in 1993. If the EC Council laid down a common standpoint on an issue covered by the EEA which would require changes to Austrian law if it was to be adopted later in the EEA Council, Austrian constitutional law made provision for the Nationalrat ${ }^{10}$ to express its agreement or opposition in a resolution. While such resolutions were not binding on the Austrian minister who would consider such a measure later in the EEA Council, decisions of the

\footnotetext{
${ }^{7}$ German original: 'zwingende außen- und integrationspolitische Gründe'.

${ }^{8}$ Austrian 'constitutional law' needs a two-thirds majority in the Nationalrat and, if Länder competencies are at stake, even the assent of the Bundesrat (Art. 44 Para. 2 of the Austrian Constitution).

${ }^{9}$ Note that the general responsibility for EU co-ordination within the Austrian 'grand coalition' government 1996-99 was split between the Federal Chancellery and the Department of Foreign Affairs, i.e. between the social democrats and the conservatives. Intragovernmental co-operation in EU affairs was tackled in two coalition agreements (in 1994 and 1996) and in a statute from 1996 (Müller, 1997).

${ }^{10}$ And, where Länder competencies were concerned, also the Bundesrat.

(c) Blackwell Publishers Ltd 2000
} 
EEA Council that impacted on Austrian law did require the acceptance of the Nationalrat in any case.

The control rights for the Austrian parliament that were set up for EU membership thus followed an existing path. In fact, both the established practice and the concerns for broad public legitimacy prior to the membership referendum facilitated the reform. In addition, a third framework condition should be mentioned: accession-related constitutional reforms had to be adopted during a period (1994-96) when the Austrian coalition government did not have the two-thirds majority needed to adopt laws of constitutional quality in parliament. The SPÖ 11 and the ÖVP 12 had been in government together since 1987 and held more than two-thirds of the parliamentary seats during most of that time, but to pass the changes required for EU membership, they needed the consent of members of the political opposition (de facto members of the minor Green and Liberal parties), who asked for far-reaching parliamentary participation and control.

\section{The Nationalrat's Rights in Practice}

Contrary to the expectations of at least some observers (Kaiser, 1995, p. 419), the actual practice of control over government by the Austrian parliament has not as yet been a success story. In fact, detailed studies show that parliament is an institutional loser in the integration process despite all constitutional precautions to protect it. ${ }^{13}$ The Nationalrat has given binding mandates to ministers in only a very few cases. During the first year of EU membership (1995) the Nationalrat was notified of 17,317 EU projects. The Main Committee discussed 100 of them and issued an opinion on 18. In 1996 and 1997, parliament received information on 37,624 matters. The Main Committee discussed 106 of them, but only 11 opinions were ultimately issued (Müller, 2000). By summer 1999, after more than four years of membership, the total number of binding opinions issued by the Austrian Nationalrat was only 31 . Furthermore, the mandates became increasingly less detailed over time (Luif, 1998).

These results are, at least to some extent, a reaction to bad experience. The most widely discussed problematic case concerned an EC directive on animal transport. The Nationalrat ruled that the relevant minister was not to allow any lowering of national standards. In the end, Austria was outvoted in the EC Council of Ministers with a solution that was not only below the national standards, but even less stringent than another compromise solution under

\footnotetext{
11 The Austrian Social Democratic Party.

12 The Christian Democratic Austrian People's Party.

${ }^{13}$ This is consistent with the results of the comparative study on the older EC members carried out by Rometsch and Wessels (1996).
}

๑) Blackwell Publishers Ltd 2000 
discussion. The Austrian delegation did not vote in favour of the latter because, reportedly, the Nationalrat could not be reconsulted in time (for details, see e.g., Griller, 1995). An amendment to the Austrian parliament's rules of procedure in 1996 provided that a standing committee on European affairs could handle most EU matters. It could even set up a committee (consisting of only one member per party) to consult on urgent matters and then report to the president of parliament. The latter could transmit this position to the Austrian representative on the EC Council. Despite the new provisions in the rules of procedure, neither of the two sub-units was as yet set up by autumn 1999 .

That Austria was outvoted on the animal transport issue confronted parliamentarians with the fact that large parts of EC decision-making cannot be directly controlled by a national parliament since many decisions are nowadays taken by majority voting in the Council. If a government is outvoted, the influence of its national parliament is curtailed, while the resulting EC norms still have to be accepted. Therefore, curing the democratic deficit of the EU unilaterally via increased control of the national parliament of one Member State is not feasible, even in principle. Experiencing this, after having lost approximately 70 per cent of their law-making powers to the EU (Müller, 2000), was a harsh lesson for many Austrian members of parliament - despite the fact that they had known about it in theory long before accession.

Even in those cases where unanimity requirements theoretically guarantee that a single national parliament, as the elected representative of its citizens, can impose its views not only on the national government, but also on the Union, members of the Austrian parliament concede that the volume and intricacies of EU legislation tend to prevent this in practice. ${ }^{14}$ The sheer number of legislative acts is too large. Furthermore, most relevant details are negotiated and de facto decided at the level of Council working groups, which interact almost permanently. Even if a national parliament wants to exert control on only a few selected topics, it needs well-trained personnel and appropriate internal structures. In the Austrian case, both seem to be lacking. Parliament's administrative capacities and specialized staff have not been increased to an extent which would allow it to deal adequately with the multitude of Euro-level decision processes needing to be 'controlled'. The work load of the Main Committee of the Nationalrat which discusses EU matters was already heavy before 1995 due to all the national issues on its agenda. Initially it met every other week to discuss EU affairs, but by the late 1990s this had been reduced to only once a month. This very low level of activity compared, say, to the Danish Market Committee of the Folketing, which is in near-permanent session (Ladrech, 1994, p. 77 with further referenc-

\footnotetext{
${ }^{14}$ For more information from extensive interviews with Austrian MPs, see Falkner and Müller (1998).
} 
es), suggests that the legal control powers of the Austrian Nationalrat are hardly being exercised in everyday politics.

A number of factors account for this development: the specific kind of government in office until 2000, comparatively better access by the government and administration to the EU level combined with their self-interest in not giving parliament much of a say, and the design of domestic-EU coordination in Austria. The first aspect is directly connected to the Austrian tradition of 'grand coalition' government (i.e. between the two largest parties) during the 1990s. The de facto distribution of powers between the national political institutions in a rather stable coalition of this type allows for the options of the government to be transmitted to the parliamentary groups via party loyalty. Coalition discipline implies that ministers are only mandated by parliament if both coalition parties agree (Müller, 1997). Considering that the two major parties which composed the Austrian grand coalition government during the late 1990s represented in the Austrian parliament more than a twothirds majority, they could dominate the political agenda not only in terms of policies, but also with regard to institutional politics. This would certainly have been different under a minority government, as is the tradition in Denmark for instance. It might even have been different under a grand coalition with only a smaller majority in the Austrian parliament. Since individual dissenting members of the governing parties would have carried proportionally greater weight, a different dynamic might have originated, which could have made the Nationalrat more assertive vis-à-vis the executive. As it is, only the members of the opposition parties have shown much interest in parliamentary activity in EU affairs. They had, however, little say in the Nationalrat and its Main Committee because of the two co-governing parties' power to pass even constitutional laws on their own (1996-99); note that the new centre-right government between ÖVP and FPÖ has less than a two-thirds majority. It is no surprise, therefore, that the small Green group in parliament especially complained that the governing coalition parties blocked the discussion of relevant EU topics in the Main Committee (see also Luif, 1998, p. 124).

Confronted with manifold new challenges at the EU level and often heavy time pressures when crafting a 'national standpoint', the Austrian government has not considered it desirable in practice to have to deal also with tough parliamentary control. The government's capacity to negotiate and, if necessary, to change its view or make concessions is valued more than giving the directly elected representatives of the citizens much of a say (Falkner and Müller, 1998). At least informally, functional criteria are often mentioned as the reasons why ministers, having just become the crucial national players within the EU, have little interest in seeing their efficiency in handling EU 
matters jeopardized by a national parliament whose internal procedures will always be cumbersome.

The administration has no self-interest in a strong Nationalrat in EU affairs, either. In fact, interviews show that information overload is a strategy frequently employed by bureaucrats to limit the practical influence of the Austrian parliament (Steiner and Trattnigg, 1998). Ministries just shower information on the members of parliament, expecting that they will not have the capacity to single out the crucial pieces and topics in time. This seems to work in many cases since the issues picked for parliamentary statements in order to bind the government have so far - at least from the viewpoint of the bureaucracy - not always been the most important ones. ${ }^{15}$ The way Austrian deputies must be informed on EU matters is in itself not conducive to allowing for effective influence. Indeed, all EU documents which the responsible members of government have at their disposal are transmitted. The obligation to inform parliament is not, however, interpreted to include specific reports by the minister, his or her point of view on the issue, or the preparation of summaries. ${ }^{16}$ There are thus significant hurdles to be overcome by the Austrian Nationalrat in the process of issuing a binding mandate to control government in EU negotiations.

Finally, parliamentary mandating runs counter to the 'normal' practice of EU co-ordination in Austria. After all, there is extensive work being done in order to generate a 'national standpoint' - in which parliament is not involved. EU co-ordination in Austria is generally managed by a ministry 'in charge' of each specific EC draft law. Within this governmental department, the person participating in the relevant Council working group will initially consult with various colleagues, interest groups, etc. Inter-ministerial co-ordination meetings follow on an ad hoc basis and include representatives of the Länder and the social partners. The weekly COREPER preparation meeting allows for the final check as to whether a coherent national position is accepted by the participating actors. It includes members of relevant ministries, interest groups, the Länder co-ordination unit, the Council of Cities and Municipalities, and the National Bank. The members of parliament, however, come in only at the very end of the co-ordination line, when an issue is being presented in the Austrian Council of Ministers. On this occasion, the representatives of the parliamentary parties have the right to participate and speak - but by then the national position is usually well designed. In short, while Austrian-EU coordination occurs in a bottom-up way under the auspices of a ministry in

\footnotetext{
${ }^{15}$ Steiner and Trattnigg (1998, p. 160). In none of the cases in social and environmental policy under inspection in Falkner and Müller (1998) did the Austrian parliament play a significant role. In the case of the EC Directive on Environmental Impact Assessment, the Nationalrat's Main Committee became active only once, and the relevant document then was three months old and already outdated (Trattnigg, 1998).

${ }^{16}$ This was explained in a circular by the Chancellery and the Foreign Ministry (Trattnigg, 1997).

(C) Blackwell Publishers Ltd 2000
} 
charge, the control by the Nationalrat over the national position, as provided for in the Austrian constitution, is designed in a top-down manner, which fits the general structure rather badly.

\section{The Länder}

\section{Efforts to Preserve National Traditions}

It was clear long before Austrian EU membership that the purely consultative Committee of the Regions would not provide the comparatively powerful Länder with an influence in Euro-politics commensurate with their domestic role. The participation of the political sub-units of the Austrian federal state was therefore regulated in Art. $23 \mathrm{~d}$ of the Austrian Constitution and in a special state-Länder agreement on the participation of Länder and districts in European integration affairs. ${ }^{17}$ That the latter agreement stems from 1992, i.e. long before EEA or EU membership, indicates that attributing special rights was a means of ensuring co-operation by the Länder in the process of EU rapprochement - an issue in which the Länder were perceived de facto to have veto power (Dachs, 1994, p. 187). The strategy paid off since the Assembly of Länder Governors (Landeshauptleutekonferenz) helped in gathering political legitimacy for the adhesion option during the Austrian membership negotiations (Dachs, 1994, p. 187; Morass, 1996). ${ }^{18}$

The procedure of Länder involvement in EU affairs resembles that of the Nationalrat, but the provinces have less far-reaching rights. The government is obliged to inform the Länder on all EU-related projects which touch their domestic realm of autonomy or might otherwise be of interest to them. This is effected by submitting all relevant documents and reports. The Länder may issue opinions on such EC projects. Their unanimous position in an area of Länder competency under domestic jurisdiction is binding for the Austrian delegation in Brussels. Abstention is of no consequence, but five out of the nine Länder must vote for any 'joint position'. Only if there are 'compelling reasons of foreign or integration policy' - which is a 'legally vague clause', however (Morass, 1997, p. 80) - may the government deviate from such positions and justify this within eight weeks.

Another concession to the Länder gained during the pre-accession phase is that they can directly participate in EU negotiations. If issues within their inner-state legislative realm are discussed, the government may include a

\footnotetext{
${ }^{17}$ BGB1 No. $7751 / 1$ 1992. It is a specific characteristic of Austria that not only the regions, but even local districts and the municipalities have been given some information and consultation rights (Morass, 1996, p. 40).

${ }^{18}$ On details of the Austrian debate concerning EU adhesion, see most importantly Schneider (1990); Luif (1995); Schaller (1994); and Schaller (1996).

(c) Blackwell Publishers Ltd 2000
} 
Länder nominee in the Austrian delegation. This representative may, however, only act in co-operation with the responsible member of the government (see Art. 23d, Para. 3 of the Austrian Constitution). ${ }^{19}$

With a view to co-ordinating their EU policies, the Austrian regions set up two bodies. The 'Integration Conference of the Länder' consists of the governors of the nine Länder (Landeshauptleute) and the presidents of the regional parliaments, but only the former are entitled to vote ${ }^{20}$ (Dachs, 1994, p. 190). In the 'Standing Integration Committee of the Länder', delegated bureaucrats support the Integration Conference. The formal link with federalEU co-ordination is established by the Länder's liaison office in Vienna (Verbindungsstelle der Bundesländer). It gathers relevant information and transmits the positions agreed in the Integration Conference, but it has no competency for aggregating regional interests. Like other Austrian institutions such as the National Bank or the Statistical Office, and in addition to the ministries, the representative of the liaison office may participate in the weekly jour fixe, where the strategy of the Austrian Permanent Representative with the EU is co-ordinated.

Last, but not least, the Austrian Bundesrat may also give opinions on EUrelated topics. This second parliamentary chamber consists of representatives of the Länder parliaments and usually has only a retarding veto in Austrian legislation. The government has to take such opinions into due account but is in most cases not bound by them. ${ }^{21}$ This is a crucial difference to the German system, where the position of the Bundesrat is binding on the Federation if no agreement can be reached with the Federal government (Goetz, 1995, p. 106).

\section{The Rights of the Länder in Practice}

While the Länder's institutional self-interests in the multi-level system will usually be parallel, their interests with regard to EU policies often diverge according to their specific economic and legal situation (Dachs, 1994, p. 203). ${ }^{22}$ Since the position of an agricultural region bordering Hungary tends to diverge from that of a highly industrialized area neighbouring Germany, unanimity is a tough condition. As soon as their wishes regarding a 'national'

\footnotetext{
${ }^{19}$ This is less far-reaching than, say, the Belgian model, which provides that the federal state may be represented and committed in the EC Council by a member of a sub-national government (Kerremans and Beyers, 1997, p. 46).

${ }^{20}$ There was a controversial debate on parliamentarism at regional level, specifically on who should vote in the Integration Conference. In some Länder, the constitutions now provide for similar consultation and mandating processes of the Landeshauptleute and Landtagspräsidenten, as exists between parliament and government at the federal level (Dachs, 1994, p. 190).

${ }^{21}$ Where EU projects would lead to changes in Austrian constitutional law which would need the Bundesrat's assent under domestic rule, departure from an opinion of the Bundesrat is, however, only legal if there are compelling reasons of foreign and integration policy.

${ }^{22}$ For a similar statement on Germany, see Jeffery (1997, p. 69).

() Blackwell Publishers Ltd 2000
} 
position differ, however, the Austrian Länder cannot encroach on the strategy of the national minister in the EC Council. For this reason, unanimous and hence binding opinions of the Länder are in practice very rare (Morass, 1997, p. 82; Steiner and Trattnigg, 1998, p. 164). If such joint Länder opinions were adopted during the early years of Austrian EU membership, it was uncontroversial to make them the 'national' position because the interests of the federal and the regional level in Austria were usually closer to each other at the time than they were to the positions of the other Member States (Morass, 1996, p. 41).

In day-to-day practice, the Länder have even more difficulty in keeping up to date with EU negotiations than parliament. The deadlines and time pressures of Euro-politics impinge on the Länder even more than on actors at the federal level. The geographical distance between them means comparatively greater difficulties in reaching joint opinions. Intricate bureaucratic procedures have to be followed in nine different locations when drafting a regional viewpoint, then all nine positions should ideally be aggregated despite often divergent interests. In urgent matters, the Länder's liaison office in Vienna thus frequently communicates nine different opinions (Steiner, 1998, p. 54). These may counteract each other in the process of drafting a single 'national' position. Instead of having the inflexible liaison office participate in national EU coordination, the Länder have meanwhile started nominating specific Länder representatives for specific EU-related issues. They usually come from two different regional governments and try to represent the interests of all Länder during the elaboration of an Austrian standpoint (Steiner and Trattnigg, 1998, p. 164). In any case, the Austrian position is usually already worked out by the time the Länder representative(s) participates in the weekly jour fixe, where the strategy of the Austrian Permanent Representative with the EU is co-ordinated. By contrast, the earlier co-ordination meetings (which are more important in practice) are organized by the ministry responsible for the specific Act, and the attitudes of the single departments with regard to inviting experts and representatives of institutions differ a lot (for details, see Karlhofer and Tálos, 1996, pp. 147-9).

Although Länder representatives may be included in the Austrian national delegation to the EC Council when matters within their inner-state legislative realm are discussed, this has been very rare so far (Morass, 1997, p. 84). It used to be practised in informal meetings of the Council of Country Planning Ministers. In day-to-day politics, the Austrian government claims that it may legitimately represent Austrian national interests in their full range at the European level (Weber, 1996), including the interests of the Länder. ${ }^{23}$ The

${ }^{23}$ It should be noted that, during the early phase of membership, complaints were voiced that the federal government used its tactical advantages at the EU level to the detriment of the Länder. For example, the

(C) Blackwell Publishers Ltd 2000 
latter have accepted this for practical reasons: if their position on a matter is unanimous, there is usually no problem in having it represented by the government as the 'Austrian' position. If their positions differ, they cannot present a single voice in the EU Council.

A significant setback for Austrian federalism is that the planned reform of the Bundesstaat, which was intended to counterbalance losses of the Länder in the multi-level political system of the EU, was not adopted. According to a 'political agreement on the reform of the federal state' signed by the Federal Chancellor and the chairman of the Landeshauptleutekonferenz (Conference of the Länder Governors) in 1992, innovations should have focused on the following: distribution of competencies between federal, regional and local level; creation of coherent clusters of competency for the Länder; reinforcement of their constitutional autonomy; possible strengthening of Länder powers with respect to EU affairs; and reforms of the Bundesrat as well as of the budgetary distribution between the various state levels (Dachs, 1994, p. 192). The agreement stated that the reform should be completed not just before EU adhesion, but even before the Austrian referendum on membership.

However, this never happened. A draft law, agreed upon only after some delay in the constitutional committee of the Austrian Nationalrat, fell far short of the initial stakes (for details, see Weber, 1996, pp. 56-7). Most notably, no coherent fields of Länder competency were delineated. Rather, the overall distribution of competencies between the federal and the regional level of government would have made the situation even more of a maze. In addition, the unpredictable financial costs of various aspects of the envisaged reform (above all, the setting up of regional administrative courts) made the Länder reluctant to press ahead. Finally, without prior consultations the federal government initiated some new amendments to the draft which would have been to the detriment of the regions. The Bundesländer then preferred no reform of the Austrian federal state as the lesser evil - at a time when their political support for EU accession had already played its part as hoped for by those campaigning for membership.

\section{The Social Partners}

\section{Efforts to Preserve National Traditions}

To get the Austrian electorate to vote for EU membership, the agreement of the crucial Austrian interest groups was de facto at least as indispensable as the

\footnotetext{
Austrian membership fees to the EU were collected from the Länder much earlier than they were actually passed on; payment to the Länder of EU regional development funding from the EU, in turn, was delayed by the government (Weber, 1996, pp. 61-2).
}

(C) Blackwell Publishers Ltd 2000 
agreement of the Länder. ${ }^{24}$ Since the major interest groups feared that 'significant parts' of their powers in national policy-making would be transferred to Brussels (Sozialpartnerstellungnahme, 1989, p. 157, translation by the author), Austria tried to counterbalance this (for a detailed overview see Karlhofer and Tálos, 1996). As early as 1989, a party agreement between SPÖ and ÖVP promised that the long-standing practice of social partner participation in the shaping of Austrian social and economic conditions would be upheld even during EU membership.

The 1994 'Europe Agreement' between the Austrian coalition parties allocated specific participation rights at the European and domestic levels to the four social partner institutions. These major associations were even promised 'equal' participation in the various EU decision-making bodies and committees. ${ }^{25}$ To guarantee social partner influence in domestic decisionmaking on EU-related matters, the right of the chambers of business and of labour to be consulted on national legislative projects proposed by the government was extended to EU issues. It was an innovation in the Austrian system of social partnership that even the two associations based on private law (the trade union confederation ÖGB and the agriculturally based PRÄKO) were legally granted consultation rights. The four classic social partner associations now must not only be informed on all EU-related legislative projects, but also given proper time to issue opinions. They are furthermore members of the External Economic Policy Committee, ${ }^{26}$ which consults the Economics Ministry on EU-related issues. During the preparation of Austrian EU positions, the social partner associations participate in relevant meetings, which are organized at the sub-ministerial, departmental and cross-ministerial levels (for details, see Kittel and Tálos, 1999).

\section{The Social Partners' Rights in Practice}

Soon after the Austrian adhesion, the government qualified its concession that the social partners could participate in the Austrian delegations to EU decisionmaking bodies on an equal footing. It argued that, according to EU rules, only government representatives are officially part of national delegations. For special cases, the minister responsible nevertheless agreed to include social partner representatives in the national delegation, although without the right to speak (Karlhofer and Tálos, 1996, p. 141). This came as no surprise to those

\footnotetext{
${ }^{24}$ The fact that the groups representing labour opted for accession at a very early stage of the debate (against large sections of their own rank-and-file) was a crucial development. For a long time the constituency of the Chamber of Commerce was more sceptical than its official representatives, too (Austrian companies being predominantly small or medium-sized).

25 '[G]leichberechtigte Teilnahme an der österreichischen Entscheidungsvorbereitung und Entscheidungsfindung im Rahmen der EU' (pt. 13a).

${ }^{26}$ The other members are the federal ministries and the National Bank (Karlhofer and Tálos 1996, p. 142).

(c) Blackwell Publishers Ltd 2000
} 
familiar with EU law and practice. ${ }^{27}$ In any case, the direct participation in the EU Council of economic interest representations has defacto been a secondary factor only. The main reason is a practical one: sitting in meetings of the Council or its working groups can provide access to some interesting information and the chance to monitor the actual behaviour of the Austrian government, but it is very expensive in terms of resources. Therefore, the social partner organizations attend such forums very selectively and only in their core areas of interest (Falkner and Müller, 1998).

Nevertheless, the social partners seem very satisfied when asked about their role in the shaping of Austrian positions in the EU Council during the early years of EU membership (Karlhofer and Tálos, 1996, p. 143; Eder and Hiller, 1998). However, there are differences between policy areas (indirectly mentioned in Karlhofer and Tálos, 1996, p. 143) which have recently increased (Kittel and Tálos, 1999), social affairs being the field with best practice from the economic interest groups' point of view. In other policy areas, they are not equally satisfied with their role in national-EU co-ordination. The finance ministry is known to consult very infrequently (Karlhofer and Tálos, 1996, p. 145). In the field of agriculture, there were complaints during the late 1990s that unilateral steering increasingly replaces more co-operative patterns. ${ }^{28} \mathrm{In}$ the light of the concessions prior to EU accession, it is important to note that consultation (as granted by law to the Austrian social partner institutions) does not yet guarantee that interest group positions are actually incorporated into the Austrian 'national position'. In principle, the same is true for consultative rights in national politics, but the multi-level system brings in more competing interests. Furthermore, surveying the national representatives' behaviour and following up one's own positions are de facto more difficult and timeconsuming abroad. It is in keeping with domestically established traditions that, according to interviews, the problem of not only acquiring a voice but having an impact is comparatively more relevant in policy areas where corporatism had not been the prevailing mode even before EU adhesion (such as in environmental policy, see Steiner and Trattnigg, 1998).

Potential indirect effects in the sense of a trickling down of pluralist patterns of interest politics from the EU level are much more difficult to assess, at least in the short run, than the practice of incorporating interest groups in the making of EU-related decisions. What is evident, at least, is that in the core area of

\footnotetext{
${ }^{27}$ In theory, the issue could have been dealt with somewhat more in line with the Austrian 1994 'Europe Agreement' if so desired. One option would have been to provide that both official and unofficial parts of the Austrian Council delegation need to agree on votes. In practice, however, it is hard to see how divergent special interests within the delegation could have been overcome fast enough to avoid immobilizing the Austrian delegation and weakening its position in the Council negotiations.

${ }^{28}$ Thanks to Emmerich Tálos for this information.
} 
Austrian social partnership (i.e. labour law and labour market policy ${ }^{29}$ ), the corporatist patterns were not affected by the entry in the European multi-level system since a similar policy-making style was recently developed under the Maastricht Social Policy Agreement (which was incorporated in the EC Treaty at Amsterdam: Falkner, 1998a). ${ }^{30}$ It is therefore no surprise that Austrian social partnership was able to maintain its grip in this core field. With regard to national EU co-ordination, the collaboration of the social partners has so far worked out very well, favoured by the fact that the Ministry of Social Affairs has been used to corporatist policy concertation for a long time (in addition, the ministers have until 2000 come from a strong union background, which in the past has been a central qualification for this post in Austria).

Finally, it should be mentioned that the social partners were once again privileged during the preparation of Austrian EU adhesion. Other interest groups were neither guaranteed information (which is an important resource for the social partners) nor consultative rights. It is thus no surprise that environmental groups, for example, now claim to have an even harder life than before EU accession (Steiner and Trattnigg, 1998). It seems that what Beate Kohler-Koch (1998) concluded for the regions also holds true for interest groups: Europeanization offers manifold additional opportunities for all national actors, but only the ones with adequate resources can actually seize them. In the Austrian case, it was the already dominant interest groups who became comparatively stronger again, i.e. the traditional 'social partners'. Even they, however, have to (re-)focus now on the most immediate interests of their clientele. Dispersing their activities would not be much use in the overcrowded conditions of Euro-politics (Richardson, 1996). This might, in the long run, reinforce the already existing trend towards a sectoralization of national interest-politics that was recently acknowledged even for the corporatist 'role model case' of Austria (Kittel and Tálos, 1999; Kittel, 2000).

\section{Conclusions}

Since membership of the EU was expected to have a rather strong impact on the traditional Austrian model of politics, the basic institutions of the national

\footnotetext{
${ }^{29}$ It should be mentioned here that Austrian social partnership is less uniformly characterized by interest group codecision in public policy-making than is often assumed. In areas such as judicial policy, education, research policy, consumer protection, defence policy and telecommunications, the influence of the Austrian social partners is at best marginal (Kittel and Tálos, 1999, pp. 118-19). In fact, corporatist patterns are dominant in a few core policies only (i.e. in social, economic and agricultural policies). Even there, they do not characterize all issue areas and, certainly, not each and every specific decision process. ${ }^{30}$ For a comparison of the effects of EU membership on Austrian policy networks in the environmental versus social policy fields, see Falkner and Müller et al. (1999). With regard to other areas, additional studies are needed which compare the specific policy network at the EU level with the one pre-existing at the national level and study possible feedback mechanisms (Falkner, 2000).
}

(c) Blackwell Publishers Ltd 2000 
political system which were expected to lose out under the conditions of Europolitics (notably parliament, the Länder and the social partners) were accorded special rights in EU-related decision-making. Existing domestic structures thus had a decisive influence on the legal reforms - and even some constitutional ones - which aimed at counterbalancing the effects of Europeanization in Austria (Luif, 1998, p. 119). Both parliament and the Länder were empowered to formulate bargaining mandates for the Austrian minister in the EC Council. The social partners were granted a privileged flow of information as well as participation at both the domestic and European levels of decisionmaking in economic and social matters. In political practice, however, the characteristics of Euro-politics proved to be quite resistant to this national counterbalancing, even if the latter was performed at the constitutional level.

What kinds of factors account for this? In the light of the more general hypothesis that European integration impacts not only on national policies but also on national politics, the important question is whether the conditions leading to this outcome were country-specific or general in character. It seems that both kinds of factors were at work. Country-specific conditions are, first, the design of the codecision powers for non-governmental actors involved in EU-level decisions and in intra-Austrian EU-related policy-making. One example is that the Länder have to adopt unanimous viewpoints if they want to mandate the government which represents Austria in the EU Council of Ministers. A second 'home-made' factor is the specific political framework conditions under which the participation mechanisms as designed in (constitutional) law have historically been put into practice. The stable 'grand coalition' government 1987-99 plays a major role here, as does the consensual culture of Austria's political system (which in real terms has during the second half of the twentieth century meant a consensus between the Social Democrats, the People's Party and their related social partner organizations). Since 1996, when the SPÖ and the ÖVP even regained the two-thirds majority needed for the adoption of constitutional law, the opposition has de facto had very little say in parliament (this might change under the new government without 'constitutional majority', in 2000). Members of the grand coalition, in turn, have been subjected to the Austrian tradition of coalition discipline. Since defection is costly, the government leaders can usually impose their views on party affiliates in parliament. National factors have thus clearly mattered in the application of the Austrian 'counterbalancing measures' in day-to-day politics since EU accession.

In addition, general features of the multi-level system also contribute to the fact that Europe 'sticks' more than some had thought prior to Austrian membership. Most prominently, the executive-based decision model at the EU level cannot be overriden unilaterally in (present or future) Member States, 
although at least four instruments are available in principle. First, there are EUlevel representation rights, which can only be vested in subnational governments since Art. 203 ECT provides that each Member State must be represented in the Council by a minister. This may be a member of a regional government (as Belgium desired), though this minister must still be authorized to commit the entire Member State. Only the minister may vote on the Council. If a minister cannot attend, his or her place may be taken by a civil servant who cannot vote. Only a Council member in the strict sense can vote or act on behalf of another minister (Art. 9.3 of the Council rules of procedure, OJ L/99 147/ 13). Second, participation rights in Council meetings may be granted not only to civil servants, but also to representatives of private interests. ${ }^{31}$ They are then part of a national Council delegation, although they cannot speak or vote. Third, control rights can be established. According to EU law, however, members of the Council commit their Member State (even in cases where his or her vote might not have conformed to the government's position). Nevertheless, Member States may try to bind the representative in the Council, in national law, to opinions issued by domestic actors such as parliaments or regions. ${ }^{32}$ Finally, a fourth national option for counterbalancing the executiveoriented bias of Euro-politics is to allow for participation in domestic EUrelated decision-making.

The Austrian case, where all but the very first forms of countersteering were applied, indicates that, at the moment of EU membership, the national executives still become the predominant decision-makers at the European 'first level' (i.e. the EU: Jeffery, 1997) and that they have a self-interest in being flexible (i.e. not tightly controlled) in Council negotiations. In fact, all potential measures allow for quite limited counterbalancing only. As outlined above, some legal factors restrict the individual Member State's leeway (e.g. the EU Council's rules of procedure providing for votes by ministers only, or the fact that governments may nowadays be outvoted on most decisions). Experience in Austria suggests, however, that they are less significant in overall terms than such practical issues as scarce resources (most notably in the case of interest groups), co-ordination problems (in particular for regions) and overcrowded agendas (e.g. for national parliaments). Such problems are crucial enough in national politics, but their salience increases when secondlevel actors (i.e. national ones) get involved in first-level issues on top of their domestic responsibilities. Similarly, deliberative institutions (e.g. parlia-

\footnotetext{
${ }^{31}$ In practice, the term 'officials' is interpreted in a wide sense since Art. 4.4 of the Council rules of procedure provides that members of the Council 'may be accompanied by officials who assist them'. The Council may lay down the number of such officials, but meetings restricted to only the ministers are also possible (Art. 4.4).

${ }^{32}$ This will usually be sufficient since the political career of a minister is decided at the national level as well. However, monitoring is in fact often difficult to manage from the domestic level since viable and timely information on the other delegations' options is rarely available.
}

(c) Blackwell Publishers Ltd 2000 
ments) and institutions with unanimity requirements (e.g. the sum of Austrian regions if they want to bind the central government) are, in each political system, at a disadvantage compared to hierarchical actors in terms of decision speed. This is, once again, aggravated under the conditions of the European multi-level system, characterized by increased time pressures as well as by multiplied interests and procedures.

Even if, in a given future EU Member State, the domestic conditions might be more favourable for day-to-day control of the national ministers in the EU Council, ${ }^{33}$ the character of Euro-politics will tend to strengthen the government and the administration compared to other national actors (on the so-called 'strength of weakness', see Kohler-Koch, 1996; Grande, 1996b). Whether this is considered a welcome escape from 'agency capture' (i.e. from a situation where, say, economic interest groups can dominate any national reforms) or rather an 'agency loss' (in the sense that the governments gain too much autonomy from their parliament and electorate) is largely a matter of perspective. In Austria, more autonomy for the government tends to be welcomed in the case of the relationship between the government and the social partners, given that the latter were particularly powerful in the past and, since the mid1980 s, often perceived as a hindrance to structural reforms. At the same time, increased de facto powers for the executive tend to be criticized in Austria where parliament is concerned, whose influence in political practice was often meagre even before 'Europeanization'.

This study confirms earlier insights, relating to other Member States, that European integration impacts on federalism, parliamentarism and publicprivate relations (see, e.g., Goetz, 1995; Ladrech, 1994; Börzel, 1999; Rometsch and Wessels, 1996; Schmidt, 1996, 1997, 1999a, b). Where a detailed analysis of the effects of European integration on national institutions is concerned, ${ }^{34}$ however, the Austrian case suggests that it is essential to employ a rather ambitious research design. It reveals the crucial importance of differentiating between policy areas, between the theory and practice of national provisions, and finally between different pre-existing national models in the analysis of Europeanization and national politics.

\footnotetext{
${ }^{33}$ For example if there are minority governments, no culture of 'coalition discipline', no unanimity requirements for mandates by the regions.

${ }^{34}$ It should be pointed out that this research question goes beyond the issue of 'convergence' (on the latter, see particularly Rometsch and Wessels, 1996, pp. 357-60). Federalism may serve as an example since a convergence towards the German model of co-operative regionalism was recently detected among the federal EU Member States (Börzel, 1999). That the present end point of developments in a number of domestic systems is similar (e.g. co-operation in the intra-state process of EU-related policy-making) does not mean that the impact of Euro-politics is the same everywhere. The diagnosis of impact needs to take into account possible different starting points. Since the pre-existing model of federalism differs between Austria and Germany, the effects of Europeanization would not be the same even if the result were identical.
} 
The importance of the meso level is most striking as regards the impact of Europeanization on national patterns of public-private interaction in policymaking. It is useful, but not enough, to differentiate according to more statist, pluralist or corporatist Member States. Even in the case of the so-called corporatist role model, Austria, public-private relations differ from area to area. Further sectoralization is promoted by the great differences in interest politics prevailing at the EU level. While many fields are characterized by lobbying of diverse small interest groups (e.g. environmental policy), some fields have an outright statist character with no significant role for private interests at all (e.g. monetary policy). Finally, the Maastricht Treaty established a corporatist policy community for social policy where a few privileged interest groups are co-actors in public decision-making (Falkner, 1998a). It is thus no longer reasonable to expect similar signals to trickle down from the European 'first level' across the various policy fields. Whatever influence comes top-down will, furthermore, meet varying conditions in different areas, even within the same Member State. Hence, no simple general statements on adaptational dynamics can be ventured. ${ }^{35}$

The potentially great contrast between law and practice is best underlined by the application of control rights over governments in EU affairs. Studying the formal set-up and the legal rules of various national European Affairs Committees and scrutiny processes (Bergman, 1997) remains without doubt an interesting academic endeavour. However, only work that includes the dayto-day application of such formal rules will bear results of immediate relevance. Austria is a case in point, demonstrating that far-reaching parliamentary powers do not necessarily mean tight control in practice, and anyone examining only the national constitutional provisions to that effect will be misguided.

Another lesson from the Austrian case is that the impact of European integration on the regional actors depends on the model of federalism in a specific Member State. It may be a generalizable fact that 'EC inputs may provide additional conduits of resources and political legitimacy for subnational actors' in unitary states (Ladrech, 1994, p. 85). The effect of EU membership on federal states is, nevertheless, not necessarily uniform. Rather, it depends on the specific federal-regional relationship within the state, as the comparison between Austria and Germany indicates.

Klaus Goetz has convincingly argued that European integration has actually reinforced several of the key principles of German federalism (Goetz, 1995). That the Austrian case deviates from this is mainly due to its different national model. Austrian federalism is less characterized by the sharing of

\footnotetext{
${ }^{35}$ As I have outlined elsewhere, the probable long-term result might be more intra-state divergence in interest intermediation patterns alongside fewer inter-state differences within the EU (Falkner, 2000).

(c) Blackwell Publishers Ltd 2000
} 
powers and responsibilities than the German version. ${ }^{36}$ Therefore, the legislative competencies which remain with the Länder matter more, and the shift of policy-making powers to the EU level has been a more painful loss to the Austrian Länder. When it comes to EU decision-making, the Austrian government can nevertheless always act against an opinion of the Bundesrat and even against a unanimous view of the Länder (which is rare), as long as there are 'compelling reasons of foreign or integration policy'. In Germany, it is the Bundesrat which can impose its view if no agreement is reached with the federal government (Goetz, 1995, p. 106). Here we see another difference in the two models of federalism, since the second parliamentary chambers in the two countries also have a different set-up. In Germany, the regional governments send representatives to the Bundesrat. In Austria, it is the regional parliaments who are represented at the national level.

The dominance of the executives in the domestic intergovernmental process is indeed another crucial difference with respect to the impact of Europeanization on national federalism in Germany and Austria. It represents a traditional pattern in Germany, ${ }^{37}$ but a rather new one in Austria. The provision that the regional governors' unanimous position has to be taken into due account by the Austrian government (not the Länder parliaments' or at least the Länder parliament presidents' position) has been controversial. In the end, however, the proponents of an executive-based solution had good functional arguments since only timely input into EU decision processes makes sense. Contemporary politics in the European multi-level system clearly do not favour deliberative decision processes in the constituent units. Rather, centralization and hierarchy are appropriate means of assuring that regional inputs stand a chance of being taken into consideration. Decision speed will be higher if the small group of nine governors has control rights over national EU positions than if nine regional parliaments need to come to a unanimous decision. This was in the end accepted by the parliamentarians in the Austrian regions. It stands to reason that such efficiency considerations will often work as functional imperatives in the multi-level system.

Taking these results into account, it seems essential for forthcoming studies of the effects of Europeanization on national politics not to overgeneralize, but rather to explore further empirical cases both in detail and in practice. Four issues should be distinguished and each studied empirically: first, the typical features of the national system under inspection; second, the impact on the

\footnotetext{
${ }^{36}$ Approval by the Bundesrat of federal laws is necessary in the majority of cases in Germany (Goetz, 1995, p. 95); usually none of the levels can impose its views (and unanimity is frequently the rule in decisiontaking). In Austria, the Bundesrat is rarely important (basically only when the distribution of competencies between the layers of the state is at stake) and it usually has only a retarding veto in the legislative process. ${ }^{37}$ Germany is the only country where the regional governments actually have a direct say in federal lawmaking (Scharpf, 1999, p. 3).
} 
national system emanating from the EU (or rather the direction of reform incentives stemming from the supranational level); third, institutional adaptations at the Member State level, which may seek to counterbalance effects of EU adhesion; finally, the actual effects of Europeanization in day-to-day politics. As in the Austrian case, empirical studies taking into account all of these features might reveal that the specifics of Euro-politics are more pervasive than one would conclude from only considering a selection, but that the effects of Europeanization on particular domestic systems are less uniform than otherwise expected. ${ }^{38}$

Correspondence:

Gerda Falkner

Max-Planck-Institute for the Study of Societies

Paulstrasse 3, D-50676 Köln

Tel: 00492212767180

Fax: 00492212767555

email: falkner@mpi-fg-koeln.mpg.de

\section{References}

Abromeit, H. (1998) 'How to Democratise a Multi-level, Multi-dimensional Polity'. In Weale, A. and Nentwich, M. (eds), pp. 112-24.

Bergman, T. (1997) 'National Parliaments and EU Affairs Committees: Notes on Empirical Variation and Competing Explanations'. Journal of European Public Policy, Vol. 4, pp. 373-87.

Bieber, R. (1997) 'Reformen der Institutionen und Verfahren - Amsterdam kein Meisterstück'. integration, Vol. 20, pp. 236-46.

Börzel, T. A. (1999) 'Towards Convergence in Europe? Institutional Adaptation to Europeanization in Germany and Spain'. Journal of Common Market Studies Vol. 37, No. 4, pp. 573-96.

Brok, E. (1997) 'Der Amsterdamer Vertrag: Etappe auf dem Weg zur europäischen Einigung'. integration Vol. 20, pp. 211-18.

Dachs, H. (1994) 'EU-Beitritt und die Bundesländer'. In Gerlich, P. and Neisser, H. (eds), pp. 185-208.

Dachs, H., Gerlich, P., Gottweis, H., Horner, F., Kramer, H., Lauber, V., Müller, W. and Tálos, E. (1997) Handbuch des politischen Systems Österreichs (Wien: Manz).

Eder, M. and Hiller, K. (1998) 'Sektorstudie Sozialpolitik' . In Falkner, G. and Müller, W. C. (eds), pp. 39-78.

\footnotetext{
${ }^{38}$ This might hold true even in cases where convergence towards similar institutional solutions exists, as the comparison of German and Austrian state-Länder co-operation indicates (see above).

() Blackwell Publishers Ltd 2000
} 
Falkner, G. (1994) 'EU-Beitritt aus demokratiepolitischer Sicht'. In Gerlich, P. and Neisser, H. (eds), pp. 71-111.

Falkner, G. (1998a) EU Social Policy in the 1990s: Towards a Corporatist Policy Community. European Public Policy Series (London/New York: Routledge).

Falkner, G. (1998b) 'Österreichische Politiknetzwerke und EU-Mitgliedschaft: Ergebnisse und Trends'. In Falkner, G. and Müller, W. C. (eds), pp. 221-48.

Falkner, G. (2000) 'Policy Networks in a Multi-level System: Converging Towards Moderate Diversity?'. West European Politics, Vol. 23, (forthcoming).

Falkner, G. and Müller, W. C. (eds) (1998) Österreich im europäischen Mehrebenensystem: Konsequenzen der EU-Mitgliedschaft für Politiknetzwerke und Entscheidungsprozesse (Wien: Signum).

Falkner, G. and Nentwich, M. (2000) 'The Amsterdam Treaty: The Blueprint for the Future Institutional Balance?'. In Neunreither, K. and Wiener, A. (eds) European Integration after Amsterdam: Institutional Dynamics and Prospects for Democracy (Oxford: Oxford University Press), pp. 15-35.

Falkner, G., Müller, W. C., Eder, M., Hiller, K., Steiner, G. and Trattnigg, R. (1999) 'The Impact of EU Membership on Policy Networks in Austria: Creeping Change Beneath the Surface'. Journal of European Public Policy, Vol. VI, pp. 496-516.

Føllesdal, A. and Koslowski, P. (eds) (1997) Democracy and the European Union (Berlin/Heidelberg/New York: Springer).

Gerlich, P. (1994) 'Regierungspolitik und Europäische Union'. In Gerlich, P. and Neisser, H. (eds), pp. 19-42.

Gerlich, P. and Neisser, H. (eds) (1994) Europa als Herausforderung. Wandlungsimpulse für das politische System Österreichs (Wien: Signum).

Goetz, K. H. (1995) 'National Governance and European Integration: Intergovernmental Relations in Germany'. Journal of Common Market Studies, Vol. 33, pp. 91-116.

Grande, E. (1996a) 'Demokratische Legitimation und europäische Integration'. Leviathan, Vol. 24, pp. 339-60.

Grande, E. (1996b) 'The State and Interest Groups in a Framework of Multi-level Decision-making: The Case of the European Union'. Journal of European Public Policy, Vol. 3, pp. 318-38.

Griller, S. (1995) 'Zur demokratischen Legitimation der Rechtsetzung in der EU'. Journal für Rechtspolitik, pp. 164-79.

Jeffery, C. (1997) 'Farewell to the Third Level? The German Länder and the European Policy Process'. In Jeffery, C. (ed.), pp. 56-75.

Jeffery, C. (ed.) (1997) The Regional Dimension of the European Union. Towards a Third Level in Europe? (London/Portland, OR: Frank Cass).

Kaiser, W. (1995) 'Austria in the European Union'. Journal of Common Market Studies, Vol. 33, pp. 411-25.

Karlhofer, F. and Tálos, E. (1996) Sozialpartnerschaft und EU. Integrationsdynamik und Handlungsrahmen der österreichischen Sozialpartnerschaft (Wien: Signum).

Karlhofer, F. and Tálos, E. (eds) (1999) Zukunft der Sozialpartnerschaft: Veränderungsdynamik und Reformbedarf (Wien: Signum). 
Kerremans, B. and Beyers, J. (1997) 'The Belgian Sub-National Entities in the European Union: Second or Third Level Players?'. In Jeffery, C. (ed.), pp. 41-55.

Kittel, B. (2000) 'Deaustrification? The Policy-Area-Specific Evolution of Austrian Social Partnership'. West European Politics, (forthcoming).

Kittel, B. and Tálos, E. (1999) 'Interessenvermittlung und politischer Entscheidungsprozeß: Sozialpartnerschaft in den 1990er Jahren'. In Karlhofer, F. and Tálos, E. (eds), pp. 95-136.

Kohler-Koch, B. (1996) 'Catching up with Change: The Transformation of Governance in the European Union'. Journal of European Public Policy, Vol. 3, pp. 35980.

Kohler-Koch, B. (1998) 'Regionale Leistungskraft und regionale Nutzenbilanz'. In Kohler-Koch, B. et al. (eds) Interaktive Politik in Europa: Regionen im Netzwerk der Integration (Opladen: Leske+Budrich), pp. 125-52.

Korinek, K. (1994) 'Interessenvertretungen im Wandel'. In Gerlich, P. and Neisser, H. (eds), pp. 133-58.

Ladrech, R. (1994) 'Europeanization of Domestic Politics and Institutions: The Case of France'. Journal of Common Market Studies, Vol. 32, pp. 69-88.

Lehmbruch, G. (1974). 'Consociational Democracy, Class Conflict and the New Corporatism'. In Schmitter, P.C. and Lehmbruch, G. (eds) Trends Towards Corporatist Intermediation (Beverly Hills/London: Sage), pp. 53-63.

Luif, P. (1995) On the Road to Brussels. The Political Dimension of Austria's, Finland's and Sweden's Accession to the European Union (Wien: Braumüller).

Luif, P. (1998) 'Austria: Adaptation through Anticipation'. In Hanf, K. and Soetendorp, B. (eds) Adapting to European Integration. Small States and the European Union (Harlow/NewYork: Longman), pp. 116-30.

Morass, M. (1996) ‘Österreich im Entscheidungsprozess der Europäischen Union'. In Tálos, E. and Falkner, G. (eds), pp. 32-50.

Morass, M. (1997) 'Austria: The Case of a Federal Newcomer in European Union Politics'. In Jeffery, C. (ed.), pp. 76-95.

Moravcsik, A. (1994) 'Why the European Community Strengthens the State. Domestic Politics and International Cooperation'. Paper given to the Annual Meeting of the American Political Science Association, No. 1994-09-01/04, New York.

Müller, W. C. (1997) 'Regierung und Kabinettsystem'. In Dachs, H. et al. (eds), pp. 122-37.

Müller, W. C. (2000) 'EU Coordination in Austria: Challenges and Responses'. In Kassim, H., Peters, G. B. and Wright, V. (eds) The National Coordination of EU Policy (Basingstoke: Macmillan), forthcoming.

Neisser, H. (1994) 'Parlamentsreform und EU-Beitritt'. In Gerlich, P. and Neisser, H. (eds), pp. 43-70.

Nentwich, M. (1998) 'Opportunity Structures for Citizen Participation - The Case of the European Union'. In Weale, A. and Nentwich, M. (eds), pp. 125-40.

Nickel, D. (1997) 'Ein Kommentar zum Amsterdamer Vertrag aus Sicht des Europäischen Parlaments'. integration, Vol. 20, pp. 219-27. 
Olsen, J. P. (1997) 'European Challenges to the Nation State'. In Steunenberg, B. and Vught, F. v. (eds) Political Institutions and Public Policy. Perspectives on European Decision Making (Dordrecht/Boston/London: Kluwer), pp. 157-88.

Richardson, J. J. (1996) 'Policy-making in the EU: Interests, Ideas, and Garbage Cans of Primeval Soup'. In Richardson, J. J. (ed.) European Union. Power and PolicyMaking (London: Routledge), pp. 3-23.

Rometsch, D. and Wessels, W. (eds) (1996) The European Union and Member States. Towards Institutional Fusion? (Manchester: Manchester University Press).

Sbragia, A. (1994) 'From 'Nation-State' to 'Member State': The Evolution of the European Community'. In Lützeler, M. (ed.) Europe after Maastricht-American and European Perspectives (Providence/Oxford: Berghahn), pp. 69-87.

Schaller, C. (1994) 'Die innenpolitische EG-Diskussion seit den 80er Jahren'. In Pelinka, A., Schaller, C. and Luif, P. (eds) Ausweg EG? Innenpolitische Motive einer außenpolitischen Umorientierung (Wien: Manz), pp. 27-270.

Schaller, C. (1996) 'Die österreichische EG/EU-Diskussion in den Ländern'. In Rothacher, A., Zemanek, M. and Hargassner, W. (eds) Österreichs europäische Zukunft. Analysen und Perspektiven (Wien: Signum), pp. 183-234.

Scharpf, F. W. (1999) 'Föderale Politikverflechtung: Was muß man ertragen - was kann man ändern?'. MPIfG Working Paper, Vol. 99, No. 3.

Schmidt, V. A. (1996) 'Loosening the Ties that Bind: The Impact of European Integration on French Government and its Relationship to Business'. Journal of Common Market Studies, Vol. 34, No. 2, pp. 223-54.

Schmidt, V. A. (1997) 'European Integration and Democracy: The Differences among Member-States'. Journal for European Public Policy Vol. 4. pp. 128-44.

Schmidt, V. A. (1999a) 'European 'Federalism' and its Encroachments on National Institutions'. Publius, Vol. 29, pp. 19-44.

Schmidt, V. A. (1999b) 'National Patterns of Governance under Siege: The Impact of European Integration'. In Kohler-Koch, B. and Eising, R. (eds) The Transformation of Governance in the European Union (London: Routledge), pp. 155-72.

Schmitter, P. C. (1974) 'Still the Century of Corporatism?'. Review of Politics Vol. 35 , pp. 85-131.

Schmitter, P. C. (1981) 'Interest Intermediation and Regime Governability in Contemporary Western Europe and North America'. In Berger, S. (ed.) Organising Interests in Western Europe: Pluralism, Corporatism, and the Transformation of Politics (Cambridge: Cambridge University Press), pp. 287-327.

Schneider, H. (1990) Alleingang nach Brüssel, Österreichs EG-Politik. Europäische Schriften No. 66, Bonn.

Seidel, H. (1989) 'Sozialpartnerschaft unter Anpassungsdruck'. In Krejci, H. (ed.) Das reiche Land (Wien: Signum), pp. 81-97.

Sozialpartnerstellungnahme (1989) Österreich und die Europäische Integration, Wien.

Steiner, G. (1998) 'Österreich bei der Entstehung der IPPC-Richtlinie. Herausforderungen und Strategien der umweltpolitischen Akteure ein Jahr nach dem EUBeitritt'. Unpublished Diplomarbeit, Universität Wien, Wien. 
Steiner, G. and Trattnigg, R. (1998) 'Sektorstudie Umweltpolitik' . In Falkner, G. and Müller, W. C. (eds), pp. 139-71.

Tálos, E. (1982) 'Sozialpartnerschaft und Neokorporatismustheorien'. Österreichische Zeitschrift für Politikwissenschaft ,Vol. 11, pp. 263-87.

Tálos, E. (1985) 'Sozialpartnerschaft: Zur Entwicklung und Entwicklungsdynamik kooperativ-konzertierter Politik in Österreich'. In Gerlich, P., Grande, E. and Müller, W. C. (eds) Sozialpartnerschaft in der Krise (Wien: Böhlau), pp. 41-83.

Tálos, E. (1994) 'Interessenvermittlung und Interessenkonzertierung'. In Gerlich, P. and Neisser, H. (eds), pp. 159-84.

Tálos, E. and Falkner, G. (eds) (1996) EU-Mitglied Österreich. Gegenwart und Perspektiven: Eine Zwischenbilanz (Wien: Manz).

Tálos, E. and Kittel, B. (1995) 'Sozialpartnerschaft - Zur Konstituierung einer Grundsäule der Zweiten Republik'. In Sieder, R., Steinert, H. and Tálos, E. (eds) Österreich 1945-1995 - Gesellschaft, Politik, Kultur (Wien: Verlag für Gesellschaftskritik), pp. 107-22.

Trattnigg, R. (1997) 'Veränderungen des österreichischen Netzwerkes der umweltpolitischen Akteure nach dem EU-Beitritt. Am Beispiel der Mitwirkung Österreichs an der Änderung der Umweltverträglichkeitsprüfungsrichtlinie'. Unpublished Masters' Thesis, Universität Wien.

Trattnigg, R. (1998) 'Fallstudie: Umweltverträglichkeitsprüfung'. In Falkner, G. and Müller, W. C. (eds), pp. 193-220.

Weale, A. and Nentwich, M. (eds) (1998) Political Theory and the European Union (London: Routledge).

Weber, K. (1996) 'Der Föderalismus'. In Tálos, E. and Falkner, G. (eds), pp. 50-66. Wimmer, N. and Mederer, W. (1990) EG-Recht in Österreich (Wien: Manz).

Zehetner, F. and Haslinger, M. (1990) Kammern, Gewerkschaften und Verbände im Recht der Europäischen Gemeinschaften. WISO-Sonderband (Linz: Institut für Sozial- und Wirtschaftswissenschaften der Kammer für Arbeiter und Angestellte). Zürn, M. (1996) 'Über den Staat und die Demokratie im europäischen Mehrebenensystem'. Politische Vierteljahresschrift, Vol. 37, pp. 27-55. 